\title{
Depression, Anxiety, Stress and Spirituality in Yoga Practitioners
}

\author{
Nandeesh Y. D ${ }^{1 *}$, Deepa Kulkarni ${ }^{2}$, Shanmukh V. Kamble ${ }^{3}$
}

\section{ABSTRACT}

The aim of the present study was to focus on the relationship of Spirituality with Depression, Anxiety and Stress of Yoga practitioners. The sample of 40 male and 40 female yoga practitioners from Hubli-Dharwad constituted the sample for study. The DASS and FACIT Spirituality scales were administered. The results revealed a Significant relationship existing between Spirituality and Depression ( $\mathrm{r}=-.54 ; \mathrm{P}<.01)$, Spirituality and Anxiety $(\mathrm{r}=-.28 ; \mathrm{P}<.01$ ) Spirituality and Stress $(\mathrm{r}=-57 ; \mathrm{P}<.01)$. Further Regression analysis revealed the significant contribution of factors like reading journal monthly, marital status and income to Anxiety, journal reading, Marital status, visiting websites of Yoga and income significantly contributed to Depression and finally reading journal, income contributed to Stress of Male and Female Yoga practitioner. The social implications of findings are discussed.

Keywords: Spirituality, Depression, Anxiety, Stress \& Yoga

Yoga represents a body of practices with an ancient history originally derived from India. In Sanskrit, the word yoga derives from “yug” meaning to yoke, referring to the discipline of aligning the mind and body for spiritual goals. ( Monier-Williams 2005) Yoga has also been practiced for potential health benefits, with increasing attention in popular culture to prevent illness and treat disease. The definition of yoga encompasses a variety of practices which may include postures (asanas), breathing exercises (pranayama), meditation, mantras, lifestyle changes (e.g., diet, sleep, hygiene), spiritual beliefs, and/or rituals. Different yoga styles utilize and/or emphasize different practices reflecting the varied practice of yoga in India and the United States.

Presently prevalence of anxiety is increasing. In Present scenario modernization and competition are among the leading causes of anxiety. Severe form of anxiety can have impact on physical and mental health (Kirkwood G, Rampes H, Tuffrey V, Richardson J, Pilkington K. 2005 ). Yoga falls into the top ten of complementary and alternative medicine (CAM) therapies (Pelletier KR, Marie A, Krasner M, \& Haskell WL 1997, Barnett JE, Shale AJ 2012). The benefits of Yoga on

\footnotetext{
${ }^{1}$ Junior Research Fellow, Dept of Social Work, Karnatak University Dharwad, India

${ }^{2}$ Student, Dept of Psychology, Karnatak University Dharwad, India

${ }^{3}$ Associate Professor, Dept of Psychology, Karnatak University Dharwad, India

*Responding Author

(C) 2016 I Y Nandeesh, D Kulkarni, S Kamble; licensee IJIP. This is an Open Access Research distributed under the terms of the Creative Commons Attribution License (http://creativecommons.org/licenses/by/2.0), which permits unrestricted use, distribution, and reproduction in any Medium, provided the original work is properly cited.
} 
depression have been studied since 1970s, the brain scans of people practicing Yoga boosted the levels of the neurotransmitter gamma-amino butyric GABA (low levels of GABA linked to depression and anxiety. Yoga and Spirituality are inseparable. Yoga is an ancient teaching that helps the persistent practitioner to achieve the spiritual enlightment. Spirituality is the art of living to find inner peace, happiness and joy. Spirituality involves living in the present.

Jhansi Rani (2004) carried out research where the practice of hatha yoga enhanced cognitive flexibility and facilitated in overcoming the interference effect. Sakthignanavel (2007) proved that the mental health of 14 weeks training through Yogic pranayama and continuous running improved mental health condition.

\section{PROBLEM AND PROCEDURE}

\section{Preamble of the study}

Yoga is the increasingly recognized as a form of mind and body medicine that integrates and individually physical, mental and spiritual aspects. Yoga has been shown to be an efficacious intervention for many different health issues particularly stresses related illness. Practitioner's report reaping many perceived benefits from yoga including health promotion, diseases prevention and social psychological benefits. Very little research has examined the role of spirituality in relation to depression, anxiety and stress of yoga practitioner.

\section{Objectives of the Study:}

1) To find the significance of relationship Depression, Anxiety and, Stress of male and female yoga practitioners with spirituality.

2) To identify the demographic factors which influence significantly Depression, Anxiety and, Stress.

\section{Main Research Problem:}

1) Do Depression, Anxiety and, Stress of male and female yoga practitioners significantly relate to their spirituality?

2) Do factors such age, gender, marital status, education, income, journal exposes, significantly contribute to Depression, Anxiety and, Stress?

\section{Hypothesis:}

The above raised questions led to the formulation of the following hypothesis

Ha1: Depression, anxiety and stress of the male and the female yoga practitioner are significantly and negatively related to their spirituality.

Ha2: The factors such as age, gender, marital status, education, income, journal exposes, significantly contributed to depression.

Ha3: The factors as age, gender, marital status, education, income, journal exposes, significantly contributed to anxiety.

Ha4: The factors as age, gender, marital status, education, income, journal exposes, significantly contributed to stress. 


\section{Design:}

In the present investigation while developing the research design depression, anxiety and stress are taken as dependent variable and spirituality is taken as independent variable.

\section{Ethical Issues:}

$>\quad$ The nature and purpose of the study was explained before administering the questionnaires.

$>\quad$ Confidentiality was assured.

\section{Sample}

A purposive sample of "forty" male and "forty” female yoga practitioners from Hubli-Dharwad cities are selected for the study.

\section{Inclusion criteria}

Only those people who are practicing yoga were included for the study and those who were practicing yoga from minimum period of one year were included.

\section{Exclusion criteria:}

Only those people who are not practicing yoga were not included for the study. And those who were not practicing yoga from minimum period of one year.

Table No: 1, Showing the mean age the number of samples of male and female yoga practitioners.

\begin{tabular}{|l|l|l|l|}
\hline Sl. No & SEX & N & MEAN AGE \\
\hline $\mathbf{1}$ & Male & 40 & 45 \\
\hline $\mathbf{2}$ & Female & 40 & 36 \\
\hline & TOTAL & 80 & \\
\hline
\end{tabular}

\section{The Measures used}

\section{DASS}

DASS scale developed by Levi bond and Levi bond(1995) was used to assess depression, anxiety and stress of the male and female yoga practitioner.

The scale compresses of 21 items design to capture depression $(\alpha=.89$; I felt that I had nothing to Look forward to), anxiety ( $\alpha=.94$; I was aware to dryness of my mouth), and stress ( $\alpha=.96$; I found it hard to wind down). With the 4 point answer scale ranging from 1(did not apply to me at all) to 4 (apply to me very much or most of the time).

\section{Spiritual Well being}

Spiritual well being scale was developed by Peterman, Fitechett and Brady in 2002. The FACITSP has two sub scales meaning/peace, which contains eight items (e.g.:”I feel sense of purpose in 
my life”). And faith which contains four items (“I find comfort in my faith or spiritual believes”). Peterman et al (2002) demonstrated the psychometric adequacy of the FACIT-SP scales. In the current study, internal consistency reliability at base line was $\alpha=.86$ for meaning/ peace and $\alpha$ $=.86$ for faith. The meaning/peace and faith subscales where moderately correlated both at study entry $(\mathrm{r}=.46, \mathrm{p}<.0001)$ and at six months $(\mathrm{r}=.39, \mathrm{p}<.0001)$.

Table No: 2, Showing the cronbach alpha for the various scale used for the study.

\begin{tabular}{|l|l|l|}
\hline SL.NO & NAME OF THE SCLAE & CRONBACH ALPHA \\
\hline 1 & Depression & .71 \\
\hline 2 & Anxiety & .78 \\
\hline 3 & Stress & .81 \\
\hline 4 & Spirituality & .78 \\
\hline
\end{tabular}

Thus, from the above table it is clear that the scales are highly reliable.

\section{Variables.}

1: Dependent Variables: Depression, Anxiety and Stress.

2: Independent variable: Spiritual.

\section{Data Collection}

In the present study primary data was collected from all the responses that are the male and female yoga practitioner. The sample was collected from the Sai institute, university yoga centre. The purpose of the visit was made known to the head of the centre. Then the researcher was introduced to the yoga practitioner after establishing a good rapport with the respondents the self report scales namely DASS, spiritual well being scale were administered on them. Information relating to the respondents' personal factors like age, gender, marital status, education, income, journal, and website were also collected from the sample.

Table No: 3, Showing the N, MEAN, SD's for depression, Anxiety, stress, and spirituality of male yoga practitioners.

\begin{tabular}{|l|l|l|l|l|}
\hline Sl.No. & Variable & N & Mean & $\begin{array}{l}\text { Standard } \\
\text { Deviation }\end{array}$ \\
\hline 1 & Depression & 40 & 42.66 & 1.68 \\
\hline 2 & Anxiety & 40 & 45.03 & 3.78 \\
\hline 3 & Stress & 40 & 43.72 & 2.84 \\
\hline 4 & Spiritual & 40 & 58.38 & 1.41 \\
\hline
\end{tabular}

An observation of the mean scores reveals that dimension of the male yoga practitioners is slightly below average.

In terms of depression it is below average (43.72), it is again average for anxiety (45.03), and for stress (43.72) was as for spirituality it is above average (58.28). 
Finally one can understand that all the variables namely depression, anxiety, stress, and spirituality are pronounced in the male yoga practitioners.

Table No: 4, Showing the N, Mean, SD's for Depression, Anxiety, Stress, And Spirituality of female yoga practitioners.

\begin{tabular}{|l|l|l|l|l|}
\hline Sl. No & Variable & N & MEAN & $\begin{array}{l}\text { Standard } \\
\text { Deviation }\end{array}$ \\
\hline 1 & Depression & 40 & 57.34 & 9.48 \\
\hline 2 & Anxiety & 40 & 54.99 & 11.72 \\
\hline 3 & Stress & 40 & 56.28 & 10.67 \\
\hline 4 & Spiritual & 40 & 41.73 & 7.77 \\
\hline
\end{tabular}

An observation of the mean scores reveal that depression of the female yoga practitioners have scored above average (57.34) and for anxiety it's again above average (54.99) and for stress it is again above average (56.28) and finally on spirituality the mean score is below average (41.73).

Finally with the obtained result one can understand that all the variables such as depression, anxiety, stress, and spirituality are more pronounced in the female yoga practitioner.

Ha1: Depression, anxiety and stress of the male and female yoga practitioners are significantly and negatively related to their spirituality.

Table No: 5, Showing the co-relation co-efficient for spirituality of male female yoga practitioners with anxiety and stress $(N=80)$

\begin{tabular}{|l|l|l|l|l|}
\hline Sl. No & Variable & Depression & Anxiety & Stress \\
\hline 1 & Spirituality & $-.47^{* *}$ & $-.28^{* *}$ & $-.54^{* *}$ \\
\hline
\end{tabular}

${ }^{*} \mathrm{p}<.05$ significant.

${ }^{* *} \mathrm{p}<.01$ highly significant.

An observation of table no 5, reveals that the male and female yoga practitioner's depression anxiety and stress is significantly and negatively co-related with spirituality. The relationship of depression ( $\mathrm{r}=-.54)$ with spirituality, anxiety (=-.28) and stress $(\mathrm{r}=-.47)$ are observed to be corelated significantly high $(\mathrm{p}<.01)$.

The stated result implies that the male and female yoga practitioners with lower depression, anxiety, stress have significantly higher spirituality. Thus, it can be inferred that depression, anxiety and stress in male and female yoga practitioner is significantly and negatively related to their spirituality.

\section{HIGHLIGHTS}

The male and female yoga practitioner with high spirituality has shown significantly lower depression, anxiety low depression, anxiety, and stress. 


\section{RESULTS OF STEPWISE MULTIPLE REGRESSION ANALYSIS OF VARIABLES SIGNIFICANTLY CONTRIBUTING TO DEPRESSION MALE AND FEMALE YOGA PRACTITIONER.}

\begin{tabular}{|c|c|c|c|c|c|}
\hline $\begin{array}{c}\text { Serial } \\
\text { No. }\end{array}$ & Factors & $\begin{array}{c}\text { Beta Co- } \\
\text { efficient }\end{array}$ & $\begin{array}{c}\text { Standard } \\
\text { Error }\end{array}$ & $\begin{array}{c}\text { Contributed } \\
\text { R2 }\end{array}$ & T Value \\
\hline 1 & Journal 4 & 11.35 & 3.01 & 0.154 & $3.77^{* *}$ \\
\hline 2 & $\begin{array}{c}\text { Marital Status 3 } \\
\text { (Divorced/ Separated) }\end{array}$ & 20.78 & 9.09 & 0.54 & $2.28^{*}$ \\
\hline 3 & $\begin{array}{c}\text { Website 2 } \\
\text { (Weekly) }\end{array}$ & -5.206 & 2.59 & 0.04 & $-2.01^{*}$ \\
\hline 4 & $\begin{array}{c}\text { Income 7 (Rs. 100000 } \\
-249999)\end{array}$ & 13.146 & 6.26 & 0.042 & $2.09 *$ \\
\\
Overall F ratio $=7.64$ \\
Overall adjusted $\mathrm{R}^{2}=.25$
\end{tabular}

A glance of the above table reviles that not reading yoga journal every day, separated or divorced, watching yoga website weekly and those in the income group of 2 lack has significantly contributed $2.5 \%$ of variance on depression can be predicted with high depression which is very highly significant $(F=7.64 ; \mathrm{p}<.001)$ not reading yoga journal daily has contributed to $15.4 \%$ of variance on depression of male and female yoga practitioner, which is again very highly significant $(\mathrm{t}=3.77 ;<.001)$. The separated/divorced has contributed to 5.4 of variance on depression of male and female yoga practitioners which is highly significant $(t=2.28 ; \mathrm{p}<.01)$. Viewing yoga website weekly has contributed to $4 \%$ of variance on depression of male and female practitioners which is significant $(\mathrm{t}=2.01 ; \mathrm{p}<.05)$. Income of 2 lakh has contributed to $4.2 \%$ of variance which is again significant $(\mathrm{t}=2.09 ; \mathrm{p}<.05)$. Thus it can be inferred from the above presentation that those who don't read yoga journal daily have significantly high depression compare to who those read yoga journal daily. Those who are separated have shown significantly high depression when compare to those who are married. Those who don't watch yoga websites weekly have shown significantly lesser depression when compare to those who don't watch. And finally those who come in the income of 2 lakh have shown significantly high depression when compare to those who earn less than 2 lakh. 


\section{RESULTS OF STEP WISE MULTIPLE REGRESSION ANALYSIS OF VARIABLES SIGNIFICANTLY CONTRIBUTING TO ANXIETY MALE AND FEMALE YOGA PRACTITIONER.}

\begin{tabular}{|c|c|c|c|c|c|}
\hline $\begin{array}{c}\text { Serial } \\
\text { No }\end{array}$ & Factors & Beta co-efficient & $\begin{array}{c}\text { Standard } \\
\text { error }\end{array}$ & $\begin{array}{c}\text { Contributed } \\
\text { R2 }\end{array}$ & t value \\
\hline 1 & Journal 4 (monthly) & 7.54 & 3.15 & 0.068 & $2.39^{*}$ \\
\hline 2 & $\begin{array}{c}\text { Marital status 3 } \\
\text { (divorced/separated) }\end{array}$ & 23.95 & 9.46 & 0.072 & $2.53^{*}$ \\
\hline 3 & $\begin{array}{c}\text { Income 4 (rs.40,000- } \\
59,999)\end{array}$ & 4.86 & 2.17 & 0.053 & $2.23^{*}$ \\
\hline
\end{tabular}

Overall adjusted $\mathrm{R}^{2}=0.161$

$* \mathrm{P}<0.05$; significant

Overall F ratio $=6.04$

An observation of the above table reveals that out of several factors, not reading journal every day, divorced/separated, and income $(60,000)$ has significantly contributed to $16.1 \%$ of variance. It means that $16.1 \%$ of variance on anxiety of male female yoga practitioner can be predicted with high degree of confidence which is highly significant $(\mathrm{F}=6.04 ; \mathrm{P}<0.01)$. Journal reading everyday is contributing to $6.8 \%$ of variance on anxiety of male and female yoga practitioner which is again highly significant $(\mathrm{T}=2.39$; $\mathrm{P}<0.01)$. Separated/divorced has contributed to $7.2 \%$ of variance on anxiety of male and female yoga practitioner which is again highly significant $(\mathrm{T}=2.53$; $\mathrm{P}<0.01)$. Income $(60,000)$ has contributed to $5.3 \%$ of variance on anxiety of male and female yoga practitioner which is again highly significant $(\mathrm{T}=2.23 ; \mathrm{P}<0.01)$.

Thus it can be inferred from the above those who don't read yoga journal everyday have shown significantly higher anxiety when compare to those who read the journal everyday. Separated/divorced people have shown significantly high anxiety when compare to those who are married. And finally those people who have income around rs.60,000 have shown significantly higher anxiety when compare to those who were more than that.

RESULTS OF STEPWISE MULTIPLE REGRESSION ANALYSIS OF VARIABLES SIGNIFICANTLY CONTRIBUTING TO STRESS MALE AND FEMALE YOGA PRACTITIONER.

\begin{tabular}{|c|c|c|c|c|c|}
\hline $\begin{array}{c}\text { Serial } \\
\text { No } \\
\end{array}$ & Factors & Beta co-efficient & $\begin{array}{c}\text { Standard } \\
\text { error }\end{array}$ & $\begin{array}{c}\text { Contributed } \\
\text { R2 } \\
\end{array}$ & t value \\
\hline 1 & Journal 4 (monthly) & 10.05 & 3.06 & 0.121 & $3.27 *$ \\
\hline 2 & $\begin{array}{c}\text { Income } 7 \text { (rs.1,00,000- } \\
2,49,999)\end{array}$ & 23.65 & 6.26 & 0.137 & $3.77 *$ \\
\hline 3 & $\begin{array}{c}\text { Income } 4 \text { (rs.40,000- } \\
59,999)\end{array}$ & 4.49 & 2.02 & 0.045 & $2.22 *$ \\
\hline \multicolumn{4}{|c|}{ Overall adjusted $\mathrm{R}^{2}=0.27$} & \multicolumn{2}{|c|}{$\begin{array}{l}* \mathrm{P}<.05 ; \text { significant } \\
* * \mathrm{P}<.01 ; \text { highly significant }\end{array}$} \\
\hline
\end{tabular}


An observation at the table reviles that 3 factors such as reading yoga journals daily, income category (1,00,000 and above) and gender has significantly contributed to $2.7 \%$ of variance on stress of male and female yoga practitioners. Can be predicted with high degree of confidence which is very highly significance $(\mathrm{F}=11.03$; $\mathrm{P}<0.001)$. Reading journal everyday has contributed to $12.1 \%$ of variance on stress of male and female yoga practitioners which is again significant ( $\mathrm{T}=3.27 ; \mathrm{P}<0.001)$. People having the income of 1,00,000 and above has contributed to $13.07 \%$ of variance on stress of male and female yoga practitioners which is highly significant ( $\mathrm{T}=3.77$; $\mathrm{P}<0.001$ ). Further income 4 has contributed to $0.045 \%$ of variance on stress of male and female yoga practitioners which is significant $(\mathrm{T}=2.22$; $\mathrm{P}<0.05)$.

Thus it can be inferred from the above that those person who are not reading yoga journal everyday have shown significantly higher stress. Those people coming the income group of 2,00,000 under group have shown significantly higher stress when compare to their counter paths. And finally those people coming the income group of 40,000 - 59,999 also contributed.

\section{DISCUSSION:}

The benefits of the practicing Yoga has been well documented, this study tried to relate Spirituality with Anxiety, Depression and Stress. The significant and negative correlation of the spirituality with Anxiety, Depression and Stress reveals that the findings are in line with the earlier studies conducted by Kirkwood, G., Rampes, H., Tuffrey, V., Richardson, J., \& Pilkington, K. (2005) carried out research evidence on the effectiveness of Yoga for the treatment of anxiety and anxiety disorders. Javnbakht, M., Kenari, R. H., \& Ghasemi, M. (2009) Participation in a two-month yoga class can lead to significant reduction in perceived levels of anxiety in women who suffered from anxiety disorders. Gura, S. T. (2002) cited that practicing yoga at the workplace taught employees to use led to reduction in Stress and risks of injury on the job. The practice of yoga has led the practitioners to have higher level of Spirituality which has contributed to lower depression, anxiety and stress.

Further regression analysis has revealed the significant contribution of factors which has led to Depression, Anxiety and Stress. Those Yoga practitioners who don't read yoga journal daily have significantly high depression compare to who those read yoga journal daily. Those who are separated have shown significantly high depression when compare to those who are married. Those who don't watch yoga websites weekly have shown significantly lesser depression when compare to those who don't watch. And finally those who come in the income of 2 lakh have shown significantly high depression when compare to those who earn less than 2 lakh Those practitioners those who don't read yoga journal everyday have shown significantly higher anxiety when compare to those who read the journal every day. Separated/divorced people have shown significantly high anxiety when compare to those who are married. And finally those people who have income around rs.60,000 have shown significantly higher anxiety when compare to those who were earning more than that. Those yoga practitioners who are not reading yoga journal everyday have shown significantly higher stress. Those people coming the income 
group of 2,00,000 under group have shown significantly higher stress when compare to their counter parts. And finally those people coming in the income group of 40,000 - 59,999 also contributed to experience of stress. These findings need further investigations.

\section{CONCLUSIONS}

Yoga practitioners have been expressed lower depression, anxiety and stress, further the experience of spirituality has been noticed in them. But there are some factors which has probably led to experience of depression, anxiety and stress in the Yoga practitioners.

\section{IMPLICATION OF THE STUDY}

Yoga practice can lead to a healthy mental health, in terms of reduced depression, anxiety and stress. Yoga practice can lead to increase in Spiritual experience of the practitioners.

\section{REFERENCES}

Barnett JE, Shale AJ.(2012) The Integration of Complementary and Alternative Medicine (CAM) Into the Practice of Psychology: A Vision for the Future. Profession Psychol:Res Pract 43(6): 576-585.

Gura, S. T. (2002). Yoga for stress reduction and injury prevention at work.Work, 19(1), 3-7.

Javnbakht, M., Kenari, R. H., \& Ghasemi, M. (2009). Effects of yoga on depression and anxiety of women. Complementary therapies in clinical practice, 15(2), 102-104.

Jhansi Rani (2004) Cognitive Flexibility and Yoga Training. Journal of Community Guidance and Research Vol 21. 3. 275-281

Kirkwood G, Rampes H, Tuffrey V, Richardson J, Pilkington K.(2005) Yoga for anxiety: a systematic review of the research evidence. Br J Sports Med 39: 884-891.

Kirkwood, G., Rampes, H., Tuffrey, V., Richardson, J., \& Pilkington, K. (2005). Yoga for anxiety: a systematic review of the research evidence. British Journal of Sports Medicine, 39(12), 884-891.

Monier-Williams MA. Sanskrit English Dictionary( 2005 )Deluxe Edition: Etymologically and Philologically Arranged with Special Reference to Cognate Indo-European Languages. Delhi: Motilal Banarsidass, 2005; 1333.

Pelletier KR, Marie A, Krasner M, \& Haskell WL.(1997) Current trends in the integration and reimbursement of complementary and alternative medicine by managed care, insurance carriers, and hospital providers. Am J Health Promot 12: 112-122.

Skthignanvel (2007) Effect of Continuous running, Yogic Pranayama and Combination of continuous running and Yogic Pranayama Practice on Mental Health. Vol 24, No. 2. 196204

How to cite this article: Y Nandeesh, D Kulkarni, S Kamble (2016), Depression, Anxiety, Stress and Spirituality in Yoga Practitioners, International Journal of Indian Psychology, Volume 3, Issue 3, No. 9, DIP: 18.01.164/20160303, ISBN: 978-1-365-13820-1 